\title{
How the use of the Septuagint influences the theologies of Acts 2 and Hebrews 1
}

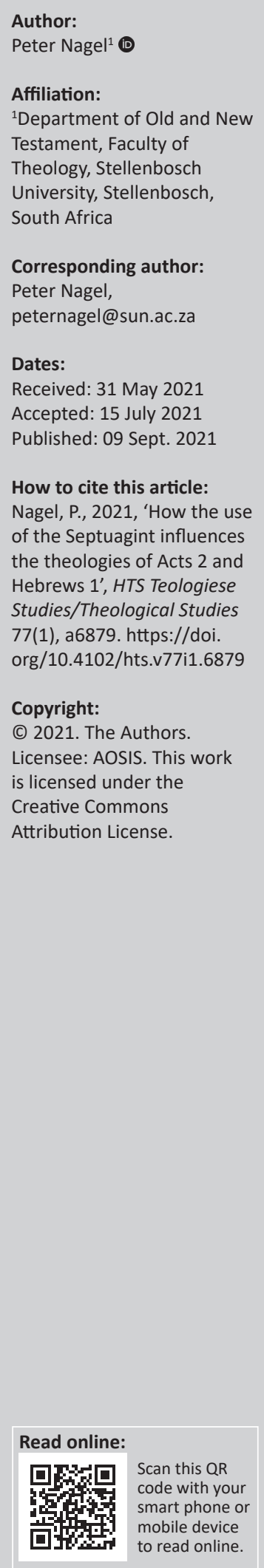

Greek versions of the Hebrew Scriptures were available to those who wanted to interpret them in light of the Jesus movement, and in relation to first century Judaism. These interpreters had a reasonable amount of freedom to use any of the exegetical methods at their disposal and to approach it from an array of hermeneutical possibilities. This was most certainly the case for the authors of Luke-Acts and Hebrews. The interest with this study is in the discrepancies, peculiarities and inconsistencies of the comparative propositions offered by the oration in Acts 2 and Hebrews 1, and whether they produce independent, alternative theologies.

Contribution: To this end, the study aims to determine to what extent the Greek Old Testament (LXX) contributes to the theologies produced in these two passages.

Keywords: Hebrews 1; Acts 2; theology; Old Testament citations; prophecy; divine speech; memory; the Son.

\section{Introduction}

The COVID-19 pandemic and the tectonic shifts on a political front taking place worldwide and how people respond to these are more often than not, underpinned by a theology. These theologies are constructed by a reflection and/or interpretation of a religious text that is considered to be authoritative. This study is an affirmation of such a reality; it will investigate how authors of the first century responded to their respective circumstances. To this end, the underlying hypothesis and value of the study is that a 'unified', 'homogenous', 'single', theology is not the answer, but rather a multitude of theologies in dialogue with one another, all of which should be scrutinised. The author of Luke-Acts narrates the day of Pentecost in such a way that it creates the expectation for a divinely sanctioned oration (Ac 2:1-4). ${ }^{1}$ To this end, the concepts conveyed in Acts 2:1-4 are convincing, but the rhetorical observation 'but wait, are those who are speaking not Galileans?' (Ac 2:7) hints that something linguistically extraordinary is happening. These Galileans spoke of the powerful deeds of Theos ${ }^{2}$ and everyone who gathered in Jerusalem could linguistically understand what the Galileans were saying, irrespective of ethnic origin and native dialect (cf. Ac 2:5-11). The narrated events are so out of the ordinary that a few were confused, some even accused them of being drunk (Ac 2:12-13). It is at this point that Peter got up to speak by way of calling to memory the prophet Joel (Jl 3:1-5) and David (Ps 15:8-11) on what Theos said about the last days.

In the case of Hebrews, the author emphatically states that during the last days Theos will no longer speak by way of the prophets, but he will speak through the Son (Heb 1:1-2a). ${ }^{3}$ This is substantiated by the author's assertion that the Son radiates the glory and the essential character of him (Theos) (Heb 1:3a), and that the Son's name is greater than that of the angels (Ac 1:4).

The notion that both Acts 2:1-13 and Hebrews 1:1-44 introduce and prepare the reader for a 'divine' act of oration is explicit and clear. Both these orations are defined, informed and substantiated by way

1.Wedderburn (1995:30) mentioned the dispute of whether the author of Luke-Acts draws from the giving of the Law on Mount Sinai in Acts $2: 1-4$. A solution to this dispute, according to him, is to interpret these verses as the author's attempt to draw a distinction between 'law giving' and 'spirit giving'. A solution that makes good sense.

2.The term $\theta \varepsilon$ ó $\varsigma$ will not be translated as to avoid any possible preconceived idea that might accompany a translation such as 'God'.

3.Steel (2010:290) uncritically asserted that 'God's' speech has been sharpened, adjusted and nuanced in the life and work of the exalted Son. Black (1987:177) wrote that a combination of the two elements (nuclear units of the colon) in Hebrews 1:1-4 confirms that God is the only agent in the event, and that one should restate the event as 'God as spoken'.

4.Meier (1985:169) asserted that the literary structure is not something alongside exegesis, but is precisely exegesis. He refers to $E$. Grässer, who in turn said of the exegesis of Hebrews 1:1-4, it is 'of the greatest importance that one understand that the stylistic care and meticulously composed structures are a factor in the author's intention' (Meier 1985:169).

Note: Special Collection: Historical Thought and Source Interpretation, sub-edited by Johann Cook (Stellenbosch University) 
of citing Hebrew Scripture (cf. Hahn 2011a:443). ${ }^{5}$ Both authors of Luke-Acts and Hebrews acknowledge, value and revere the role of Scripture as an invaluable hermeneutical and exegetical tool. ${ }^{6}$ In broad terms, they agree on using explicit Old Testament citations as an exegetical tool, ${ }^{7}$ but their hermeneutical approach and exegetical application is different. ${ }^{8}$ More fundamentally, they disagree on the method of how Theos reveals his will. This, inter alia, exposes their theological situatedness, embeddedness and intent. The result is that Acts 2 and Hebrews 1, respectively, produce interpretative possibilities representative of opposing ends of the theological spectrum. To be precise, the author of Luke-Acts is of the view that Theos speaks through his prophets (Joel and David), whilst the author of Hebrews appropriates that Theos expresses himself through his Son. It should be noticed that this study does not want to suggest that the author of Hebrews denounces or negates the role of prophecy, ${ }^{9}$ neither does it want to suggest the same for Acts 2 in relation to the Son. What it does want to highlight is the significance of the contrasting theological emphasis of both these authors. The study is therefore interested in the discrepancies, ${ }^{10}$ peculiarities and inconsistencies ${ }^{11}$ of the comparative propositions offered by the oration in Acts 2 and Hebrews 1 and whether they produce independent, alternative theologies. ${ }^{12}$ To this end, the study aims to determine to what extent the Greek Old Testament (LXX) contributes to the theologies produced in these two passages. To be able to come to such a determination, the study hypothesises that Acts 2 produces a memory-induced theology, classified as traditional universalism, whereas Hebrews 1 produces a cosmological-authoritarian theology, defined as creative traditionalism. The study further postulates that the respective propositions on offer in Acts 2 and Hebrews 1 are key to the theologies produced.

\section{Propositions}

\section{(a) Acts 2:16-17a; 2:25a}

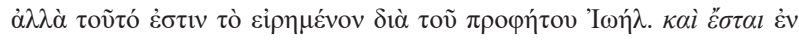

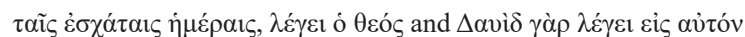

$5.01 d$ Testament, septuagint and $L X X$ are used as synonyms.

6.Longenecker (1975:93-95) mentioned the four major exegetical presuppositions that existed in early Christian preaching, namely (1) corporate solidarity, (2) correspondence in history, (3) eschatological fulfilment and (4) messianic presenceall of which are relevant for the authors of Acts 2 and Hebrews 1. Hahn (2011b:49) writes that the origin of early Christian speech is the 'Speech' and 'Thought' tradition produced by the Old Testament.

7.It is fair to assert that the author of Hebrews 1 and Acts, broadly speaking, used Old Testament citations as prooftexts, analogy and to a lesser degree, typology.

8.Longenecker (1975) asserted that the use of Old Testament content in Acts 2:25-28 (Ps 15:8-11), and Acts 2:34b (Ps 109:1) in particular, is used as analogies (the exegetical principle of gezerah shawah). Longenecker (1975:174) further wrote that the author of Hebrews interprets the Old Testament from a Christocentric perspective, and in continuation with the Christian exegetical tradition.

9.In the context of Hebrews, it does, however, appear as if the author is less interested in the prophecies (cf. Heb 2:13 [Is 8:17, 18; 12:2]; Heb 8:8 [Jr 31:31-34]). In Hebrews $11: 32$, the author briefly makes reference to prophets in the light of sharing

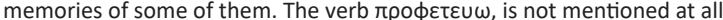

10.Discrepancies refer to the comparison between these texts with a focus on intratextuality.

11. Inconsistencies takes its cue from an intertextual focus.

12.The rationale behind the comparison between these two texts is twofold: (1) they both extensively rely on Old Testament content to argue their case, (2) historically, they both share in the socio-religious, cultural and literary conceptual context of the fourth quarter of the first century. 'but this is what the prophet Joel predicted: this is what Theos will say during the last days' and 'what David said about him (Jesus)'

\section{(b) Hebrews 1:1-2a}

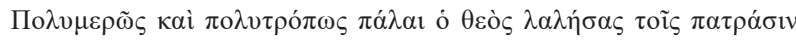

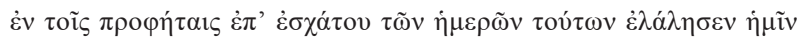
$\dot{\varepsilon} v$ vĩ

'in many different ways Theos spoke to the patriarchs through the prophets, but during these last days he spoke through his son'.

In Acts 2, Peter's speech is sanctioned by the Holy Spirit and substantiated by the prediction of the prophet Joel. This prophecy is, however, ascribed to what Theos says, $\lambda \varepsilon \dot{\gamma \varepsilon 1}$ o $\theta \varepsilon$ ćs (Acts 2:17b). To be precise, it is a predication of what Theos will be saying during the last days; these last days being the circumstances described in Acts. ${ }^{13}$ The emphasis is therefore on the subject matter of that which was orated (Joel), written down (Joel), remembered, orated (Peter) and subsequently written down (Acts). Hebrews 1, in turn, sanctions how Theos speaks; it wants to substantiate that Theos speaks through the Son. For the author of Hebrews 1, the Old Testament citations serve as authoritative proof, validation and justification that Theos speaks through the Son. Whereas for the author of Luke-Acts, the prediction about the Spirit, on the one hand, and the Kyrios, ${ }^{14}$ on the other, embedded in the citations, is what is of significance. A reasonable inference is that Acts 2 stands in continuation of a remembered Jewish tradition, and is thus only concerned about a prophetic prediction that was made in the past. For the author of LukeActs the how is implicit, and this implicitness and continuation of the tradition determines to a large degree the theology that is produced. The author of Hebrews, however, deploys a non-traditional (from the perspective of Judaism) manner of divine speech, ${ }^{15}$ which allows for a creative re-interpretation and application of tradition. It makes what is implicit explicit, so as to introduce an alternative in method and theology. The interest of this study therefore lies not only in the fact that Old Testament content shapes a theology, but how and to whom the content is ascribed. ${ }^{16}$ This study endeavours to acknowledge, appreciate and celebrate theological variety. ${ }^{17}$ It is the intention of this study to follow a literary (in the sense of a textual) approach, with emphasis on inter- and intra-textual aspects, whilst focusing on theological (as in religious) concepts.

13.The issue of whether and to what extent such an expression informs an eschatological impetus is noticed, but it will not be explored in this study.

14.The term kúpıos is not translated as to avoid possible preconceived ideas that might accompany a translation such as 'Lord'.

15. Hebrews deploys a non-traditional manner of divine speech in the sense that prophets are no longer the mediators.

16.There are other relevant questions that are brought to the fore: Are these contradictions? And if so, should these be ascribed to varying context? Is this simply a matter of textual semantics or perhaps sociocultural circumstances? Should these differences be reconciled? If one accepts the varieties offered in the New Testament, does the one weigh more than other, and if so, why? Are the New Testament, does the one weigh more than other, and if so, why? Are
both these approaches valid? What are the theological implications of these both these
varieties?

17.It can be argued that theological variety suggests relativisation, whereas uniformity can lead to interpretative blind spots and biases. 


\section{Acts 2: A memory induced ${ }^{18}$ theology: Traditional ${ }^{19}$ universalism}

Rome was a vibrant, politically infused, power ridden city during the first century. ${ }^{20}$ It was the epicentre of Roman rule, power, ideology and the imperial capital of the Roman Empire. ${ }^{21}$ It was ideally situated to 'remember' and 'reflect back' on the days when Jerusalem was the epicentre of Judaism, the 'kingdom of Israel' (cf. Ac 1:6), and by association, so too the Jesus movement (cf. Ac 1:1a-3). What better locality than Rome to 'call to memory' the idea of the kingdom of Theos (cf. Ac 1:3), an expansion of the kingdom of Israel (cf. Ac 1:6) and to acknowledge and affirm the origin of the 'universal good news' sanctioned by the Holy Spirit (cf. Ac 1:8). It is no coincidence that King David foretold the events revolving around Judas Iscariot, which forced, the then 11, to elect Matthias to become 'the twelve' (cf. Ac 1:26). It is these 12 apostles, after returning to Jerusalem for the back-to-back Sabbath and Feast of the 50 Days celebrations, who were sanctioned by the Holy Spirit to spread the ideas, principles, ethos and 'resurrection' of Jesus, the Kyrios. At this point, the focus shifted to the 12 apostles who were 'ordained' when 'tongues of fire' came upon them, symbolic of the fulfilment of the Holy Spirit, which gave them the ability and mandate to speak in different 'tongues' (languages) (cf. Ac 2:1-4). It is thus no surprise that many a devoted Judean, representing various dialects, could linguistically understand what the apostles were saying. Through reporting these events, the author resuscitates a Judean memory by triggering 'memory nodes' with concepts such as 'Jerusalem', 'Sabbath', 'David', 'Feast of 50 Days', 'devoted Judeans', 'men of Judea', 'the prophet Joel,' 'Israelites', and of course, the 'house of Israel'.22 The mere fact that the author used these concepts to trigger the relevance of the past in the present, remembering and revering the tradition. In retrospect, triggering these memory nodes ${ }^{23}$ increased the perceptibility of his audience, ${ }^{24}$ allowing him to delicately introduce and develop new theological ideas. It permitted the

18.The adjective 'induced' describes and defines the way in which memory shapes theology.

19.Traditional in this context refers to the manner through which a theology is constructed. In the case of Acts 2 , the theology is constructed by way of citing the Prophets.

20.The transition from a republic to empire forms the basis and essential nature of Rome's power and mode of governance. It lies with Roman attitudes towards powe and the appropriate behaviour of an individual, as Potter (2013:12) observed. Potter (2013) wrote that the emperor did not rule through divine right, but by virtue of a legal process that entitled him to wield power over other members of the

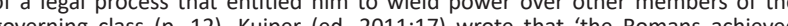
governing class (p. 12). Kuiper (ed. 2011:17) wrote that 'the Romans achieved remarked that 'Perhaps the greatest effect of all was in the city of Rome itself'.

21.Moreland (2016:345-345) wrote that the Acts of the Apostles was an early secondcentury literary attempt to reframe the collective memory by claiming the Judaean epic traditions without the need for physical memorialisation in the city of Jerusalem and that 'Christians produced stories that helped establish social memories of apostles living and dying in places like Rome...' This study adopts the assumption that both the Luke-Acts composition, as well as the Hebrews 'homily', originated in Rome during the fourth quarter of the first century; cf. Schnelle (2007:306-307, and 413-414). Such an assumption, in addition to the time of writing, further contributes to the dynamic interplay between Hebrews 1 and Acts 2 .

22.Cf. Galinsky's (2016:371-372) discussion on 'memory and history'.

23.See the discussion on the anatomy of memories in Stock, Gajsar and Güntürkün (2016:370-371).

24.The memory referred to here can be classified as declarative memory; memory that is further defined as episodic (knowledge about events we have experienced in our lives) and semantic (facts and information we have learned throughout our lifetime), see Stock et al. (2016:370-371). reader to re-imagine Solomon's portico as the Emperor's Palace at Palatine Hill. To be more precise, how does the author bridge

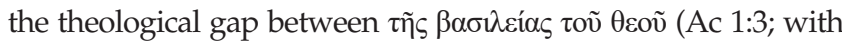

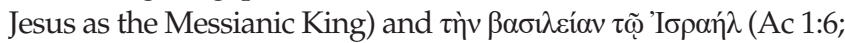
with David as the exemplary king). The most significant bridging concept is $\pi v \varepsilon \tilde{u} \mu \alpha$ 'Spirit' ${ }^{25}$ It is this $\pi v \varepsilon \tilde{v} \mu \alpha$ equipping the apostles to do great things and to witness in Jerusalem, Judea, Samaria and to the ends of the earth (Ac 1:8). If the $\pi v \varepsilon \tilde{v} \mu \alpha$ is the bridging concept, then Acts 1:8 is the fleshing out of this concept. Therefore, an author can call to memory something dear, sacred and traditional - Jerusalem - whilst situated in imperial Rome. ${ }^{26}$

It was this $\pi v \varepsilon \tilde{v} \mu \alpha$ that gave David the ability to foretell what will happen to Judas Iscariot, the $\pi v \varepsilon \tilde{v} \mu \alpha$ who gave the apostles the unique ability to speak in various dialects (Ac 2:4). It is this $\pi v \varepsilon \tilde{v} \mu \alpha$ that will be poured out on all flesh (Ac 2:17; J1 3:1), and that will cause people to prophesy (Ac 2:18; J1 3:2). This is precisely where the traditional and the new intersect, prophecy and Spirit. ${ }^{27}$ The Hebrew Scriptures form the bedrock, parameter and serve as the source of substantiation for the 'Spirit-filled prophecy' to thrive. ${ }^{28}$ Moreover, this intersection between prophecy and Spirit, traditional and universal, is embodied by Peter, one of the 12, who stands tall to address the Judean brotherhood, those living in Jerusalem, and he does so Spiritfilled, by citing Hebrew Scripture. This most certainly suggests an attempt to commingle 'an exclusive Judean religious theology' with an 'inclusive universal theology'; to be sure, it is an attempt to conflate the message of the Jesus movement with mainstream Judaism. The citations act as agents of memory with the potential to acknowledge, affirm, alienate, prove, substantiate and validate. It consists of bonding components - it has the ability to flux, connect and focus inward whilst expanding outward. It possesses the potential of both centripetal and centrifugal forces, making it ideal to mediate the bidirectional flow of traditional and innovative ideas. How else would the Galilean followers of Jesus become the 12 apostles in Jerusalem, who in turn are idealised in imperial Rome?

Peter's speech, or at least the 'remembering thereof', serves as a response to the hecklers who mocked them and accused them of being intoxicated (cf. Ac 2:13) ${ }^{29}$ it also offers a 'theological' explanation of how it is possible for 'the twelve' to speak in various dialects. ${ }^{30}$ Who better than Peter, the one

25.The essential role played by the Spirit in 'founding' the kingdom of Theos is discussed in more detail in Nagel (2018:113-127). Jervell (1998:97) commented 'Der Geist bewirkt die Wiederherstellung Israels, also der Kirche in der Endzeit. Immer wieder

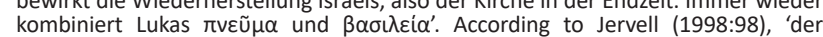
Messias ist inthronisiert auf dem Davidshtron und giesst den Geist aus'.

26.Cf. Jervell, Die Apostelgeschichte, 99. Schröter (2013:10) remarked about Christian texts that can be applied here and that is that any text does not convey direct access to reality (it is selective and interpretive), it is a medium of language that structures our access to reality and mediates between present and past; this is aptly illustrated in Acts 2 .

27.Talbert (2005:24) commented that most of the happenings in Luke-Acts are fulfilments of some kind of prophecy. Jervell (1998:142) wrote that already in Joel, the promise of the Spirit of Theos is made to the whole of Israel.

28.Cf. Jervell, Die Apostelgeschichte, 102-105.

29.Talbert (2005:27) referred to this event as 'Mockers speech', who apparently gave the incorrect interpretation of the phenomena.

30.Kilgallen (2002:74) proposed two purposes of Peter Speech, namely: (1) God has poured out his Spirit on his sons and daughters (what this experience means), (2) for everyone who calls on the name of the Lord to be saved is the ultimate divine intent (why this experience). 
who was 'supposedly' martyred in Rome, to cite what the prophet Joel foretold. Apart from what is being cited, the mere fact that it is Peter who gets up to call to mind the 'words' of a prophet as an explanation for the linguistic variety on display by the 12 apostles is symbolic as it is 'traditional'. It is therefore fundamentally important for the reader to be cognisant of 'the twelve', the prophet Joel, the devoted Judeans and the explicit citations. It is thus impossible not to frame the source content (J1 3:1-5 $5^{\mathrm{LXX}}$ ) within such a symbolical, literary conceptual framework. So, if the getting up of Peter to quote from the prophet Joel were not compelling enough, then 'placing' these words on the lips of Theos (Ac 2:17b) will most certainly achieve the necessary conceptual objectives. ${ }^{31}$ It would not be too farfetched to interpret oi vioi in Acts 2:17c as referring to

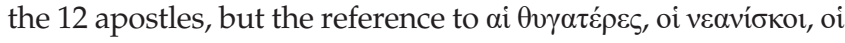

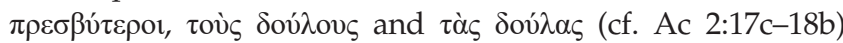
broadens the potential prophetical spectrum made possible by the $\pi v \varepsilon v \tilde{\mu} \alpha$ to be precise. The author creates a traditional, sentimental, nostalgic 'trip down memory lane' by introducing Jerusalem, the 12 apostles, the prophet Joel, Scripture and words uttered by Theos, but he most certainly made a turn down the universal, inclusive avenue, by reimagining that the sons and daughters will all prophesy if and when they are filled with the Spirit (cf. Bormann 2017:301). The theology produced here is embedded in the prophetic past, infused by memory. If such a deduction is reasonable, a logical inference would then be that the theology is not revealed from above, but is produced from within; it is to 'become aware', 'to be reminded'; it is the innovative reimaging potential of that which is called to mind. The citation is fundamental for the 'calling to memory' process, it creates the necessary checks and balances. It allows for reimagination and reinterpretation, whilst keeping things 'traditional' ${ }^{32}$ The idea of the $\pi v \varepsilon \tilde{v} \mu \alpha$ in combination with the citations is a match made in ovjpavós 'heaven'. When Peter called to memory what the prophet Joel said, he played it safe and kept it traditional. The 'newly' developed theology in Acts 2 is thus firmly embedded in the authoritative past, but the $\pi v \varepsilon \tilde{\mu} \mu \alpha$ concept allowed for a fluid reimagination of the prophecy. One cannot but admire the irony here, through a prophecy, by a Judean prophet, the sons and daughters will all become prophets and by implication would devalue the prestige that comes with being a Judean prophet. Moreover, it sets the stage for the universal programme of Luke-Acts, to adapt the inward theology to something that is directed outward.

The author is seemingly gaining confidence; this is inferred from his accusation that the Israelites crucified Jesus, something that has been foretold by Theos himself. Theos also raised him (Jesus) up from the dead, and to this end the author had to pen down what King David 'prophesied' by citing Psalms 15:8-11. The crux of David's appropriation is that he saw Kyrios (probably referring to YHWH in Psalm $15^{\mathrm{MT}}$, but it refers to Jesus in Acts) before him, and that his (Kyrios') continuous presence is a certainty. He goes on to say that 'you

31.Jerveli (1998:143) interpreted $\lambda \varepsilon_{v \varepsilon}$ ó $\theta$ cóc (Ac $2: 16 \mathrm{~b}$ ) as an indication that it is in fact Theos (transcribing is mine) that is speaking. I do not agree with this sentiment. It is overburdening this phrase. More probable is the emphasis on the prophets (Joel and David), pushing this phrase to the background.

32.Cf. Hahn (2011:583). He remarks that introduction of new concepts is dependent on the tradition. will not abandon me in Hades' (Ac 2:27). What King David supposedly foretold about the death of Jesus carries a lot of weight. As with Joel 3:1-15, Psalms 15:8-11 is an effective way to mediate between the 'not so distant past' (the tradition), and what is proposed then, and the here and now. The words of Psalms 15:8-11 would probably ignite a sense of Israelite ethnic identity, a sense of pride, power and providence. This puts the reader at ease and avoids alienation and resistance. The subtlety with which the author goes about reinterpreting the words of David addressed to $\mathrm{YHWH}$, as the words of David about Jesus, is strategically ingenious. The memory and familiarity of the Davidic monarchy is more than enough for the author to introduce something extraordinary and new: that Psalm 15 is not a Psalm of a king and his relationship to YHWH, but it is a Psalm written by David about Jesus. It is ironic, almost satirical, for the king of the Davidic monarchy to speak up and affirm the Kingship of Jesus, who will ultimately put an end to the nationalistic, traditional expectations of the return and re-establishment of the Davidic kingdom. If one would ask, but how would a king know things that will happen in the future? The answer is simple, David is also considered to be a prophet (Ac 2:30), who foresaw the resurrection of the Messiah (cf. Ac 2:31). In addition to his prophetic abilities, what the author postulates in Acts 2:34b by way of citing Psalms 109:1, is exegetically cunning.

It is apparently written that David did not ascend into heaven to sit on the right hand of the Most High, but it is in fact the Kyrios of the Kyrios who has been granted this privilege. Who exactly then is the Kyrios of the Kyrios? In the literary context of Psalms 109:1, it is Kyrios, as in YHWH, who utters these words, whereas the second Kyrios probably refers to the kingship of David. In the Masoretic Text (MT), the reference to a Hebrew deity in Psalms 109:1 is represented by the term הị: followed by אָז which, together with the pronominal suffix '., refers to an authoritative figure, probably King David, who is the presumed author's Kyrios. One should ask how the author got away with reinterpreting the identity of Kyrios. The answer is that in the citations there is enough familiar subject matter not to alienate the reader, but it allows for some interpretative manoeuvring, in this case, to reinterpret the second Kyrios as referring to Jesus. His interpretation of Psalm 109 was the only feasible one to convince the house of Israel that Theos made him (Jesus) both Kyrios and Messiah (Ac 2:36). The proposition the author is making is that the house of Israel should accept that Theos made Jesus Kyrios and Messiah and by implication the house of Israel is no longer an exclusive body of people, but it is open for all the nations, including those in Judea, Samaria and beyond.

\section{Hebrews 1 - A cosmological- authoritarian theology: Innovative traditionalism}

The proposition made in the opening lines of Hebrews (Heb 1:1-2a) sets the theological tone of this 'homily'. The premise of this supposed homily is that during these last days, Theos speaks through the Son, which seems to stand in opposition 
to the fundamentals of Acts 2, in which Theos speaks through the prophets such as Joel and David.

According to the author of Hebrews, there should be little doubt why Theos speaks through the Son; he is the heir of everything (Heb 1:2b), and all the ages came into being because of him (Heb 1:2c). More importantly, the Son also radiates the essential character of Theos, and is seated on the right hand of the Majesty on high (cf. Heb 1:3d). The author does not stop here, he goes on to argue that the name of the Son is far more superior than those of the angels (cf. Heb 1:4), followed by an extensive exposé of why the Son is more superior than the angels. It is important to mention at this point that in Hebrews 1, Theos is the dominant, in fact, the only 'orator', the one making his view known about the Son and the angels, and he does so by way of referencing Hebrew Scripture. ${ }^{33}$ The premise put forward in Hebrews 1 is thus firmly rooted in the uniquely cosmological position and authority of the Son. To argue that Theos no longer relays his message via the prophets, ${ }^{34}$ the author had to elevate the position and authority of the Son as being more superior than the angels. It is thus no surprise that the author has Theos say 'you are my son, today I gave birth to you' (Heb 1:5b-c, citing Ps 2:7c), and 'I am your father, and you are my son' (Heb 1:5c, citing 2 Sam 7:14). ${ }^{35}$ The author shows no interest in using these explicit citations to call a distant past to memory for the sake of reinterpretation and reimagination. These citations are rather deployed for the sole purpose of providing a vocabulary to Theos so that he can express his will and voice his opinion. ${ }^{36}$ There is no room and little reason for interpretation or reimagination. There is also no need to root the ideas in a prophetic past ${ }^{37}$; if and when Theos speaks, it is true, valid and beyond reproach. ${ }^{38}$ It is Theos himself substantiating the novel idea of the Son's superior authority, someone with a cosmological identity and status ${ }^{39}$ through which he (Theos) speaks. ${ }^{40}$ The cosmological abstraction of the Son's status and position in relation to Theos is augmented with intimate, familial concepts (cf. Heb 1:5b-c; 6a). The author goes as far as to introduce angelic worship of the Son (cf. Heb 1:6b). The author clearly has no interest in embedding his ideas in the history of tradition. His whole premise is

33.Guthrie (2007:1654-1655) suggested that the author of Hebrews does not take an atomistic approach to Old Testament citations, but referenced them in the light of their broader contexts.

34.In Hebrews 11:32, the prophets are mentioned amongst others, such as Gideon Samson and David, for no other reason than their faith.

35.The combination of these citations is probably the result of the gezerah shewah technique, as pointed out by Steyn (2011:29). For Steyn, these citations signify eschatological motifs of a royal Davidic Messiah (2011:29). Guthrie (2007:1667) commented that by citing Psalms 2:7, the author has exaltation theology at the centre of his thought, whereas 2 Samuel 7:14 underscores this unique relationship centre of his thought, whereas 2 Samuel 7:14
the Son shares with the Father (2011:1671).

36.Guthrie (2007:1657) pointed out that 23 of the quotations in Hebrews have God as the speaker. Schnelle (2007:595) asserted that the basis for the theological ideas in Hebrews is the divine speech, and that the speech is determined by the LXX citations.

37.Cockerill (2012:94) who argued that Christ's coming in accordance with prophecy is implicit in the Pentateuchal text.

38.Bormann (2017:361) remarked that a theology without historical communication, such as the prophets, is a daring undertaking.

39.Cf. Cockerill (2012:94) who commented that Hebrews makes excellent sense when read in terms of the heavenly word/futurist eschatology of Jewish apocalyptic.

40.Steyn (2011:30) made an important observation that in the context of Psalms 2:7 and 2 Samuel 7:14, the oracles are introduced as sayings of 'the Lord'. based on the theological idea that the Son has taken up an authoritative position as a cosmological figure. By definition, and implication, Theos had to clarify and substantiate this position in relation to the angels. If Theos is to speak through the Son, who is seated on his right hand, then the angelic privilege to access the Theos domain and relaying it to the prophets is no longer a requirement. It is for this reason that

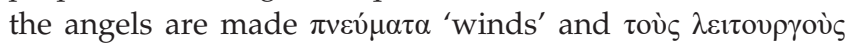
$\alpha$ vĩoṽ $\pi$ vòs $\varphi \lambda$ ó $\alpha \alpha$ 'his servants flames of fire'. It cannot be helped but to make conceptual connections with the apostles in the upper room in Jerusalem when they were $\dot{\varepsilon} \pi \lambda \dot{\eta} \sigma \theta \eta \sigma \alpha \nu$

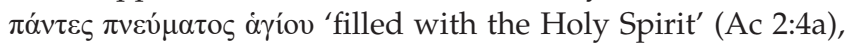

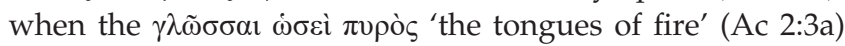
came upon them. Based on this comparison, it can be argued that the apostles are for Acts what the angels are for Hebrews; Jesus' 'absence' endorses the apostles and their authority, whilst the Son's promotion implicates the angels' demotion.

The notion of kingship is brought into play in Hebrews 1:8-9 (citing Ps 44:7-8 $8^{\mathrm{LXX}}$ ) and in part in Hebrews 1:10-12 (citing Ps 101:26-28 $\left.8^{\mathrm{LXX}}\right)$. These citations are not deployed for sentimental, traditional, 'playing it safe' reasons. It is to allow Theos to express something substantial of how he views the authority and rule of the Son. There is no compelling reason to rely on any Davidic lineage or any expectation of a prophecy ${ }^{41}$; it is narrowed down and focused on what Theos has to say about the rule of the Son, and this includes:

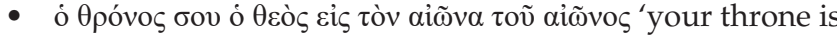
Theos forever and ever'

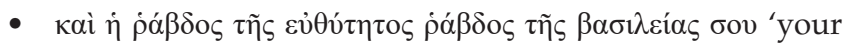
upright sceptre, is the sceptre of your kingdom ${ }^{\prime 42}$

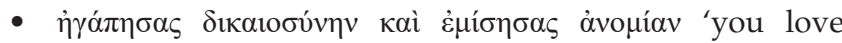
righteousness and despise wickedness'.

There is no desire on the part of the author to get David's blessing on the kingdom of the Son or to impart on him a word of validation. The divine rule of the Son does not necessitate a Davidic frame of reference, ${ }^{43}$ neither is it important whether David is the Psalmist, and what he had to say; what matters is what Theos is saying by way of the Hebrew Scriptures. The author reframes Psalm 44 from an Ode by a Korahite Psalter (Hutton 1992:101), a scribe praising the sons of Kore, a kingship group, to a claim that the Son rules with authority and does so justly, which stands in opposition to that which is claimed about the angels in Hebrews $1: 7 \mathrm{~b}-\mathrm{c}$. This is a conceptual move from a priestly collective, known for their prominence in Israelite worship and their relationship to Theos, to the substantiation of a Theos and his relationship to the Son, who has ultimate authority. ${ }^{44}$

41.Contra Steyn (2011:30) who argued that the citations from Psalms $2: 7$ and 2 Samuel 7:14 picks up on the theme of Davidic messianism, which is also applicable for the Psalms 44:7-8 citation (2011:83).

42.Docherty (2009:359), remarked that the author of Hebrews wanted to emphasise the parallelism between God's throne in the first line and the royal staff of God or the Son in the second clause.

43.The notion that Theos speaks through David in Hebrews $4: 7$ says more about the author's interpretation of who wrote Psalms 95, than how Theos expresses himself. The fact remains Theos speaks through the Old Testament citations; cf. Hahn $(2011: 444,446)$.

44.See Steyn's (2011:82-87) detailed discussion on the motif of the eternal reign of the Son and how the relationship between Theos and the Son has been understood in the early Jewish and early Christian tradition. According to Guthrie (2007:1685), Pslams 44:78 is messianic and therefore Christological. 
The citation taken from Pslams 101:26-28 (Heb 1:10-12) reaffirms the cosmological status, position and authority of the Son, whilst expanding on his just rule (Heb 1:8-9). This is

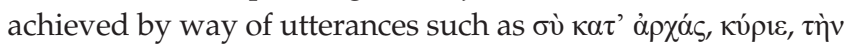
$\gamma \tilde{\eta} \nu \dot{\varepsilon} \theta \varepsilon \mu \varepsilon \lambda i \omega \sigma \alpha \varsigma$ 'in the beginning you laid the foundation of

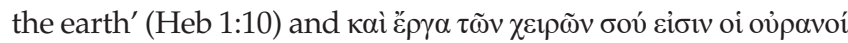
'the heavens are the work of your hands' (Heb 1:10). In Psalms $101^{\mathrm{LXX}}$ these utterances are directed at Kyrios as in YHWH (cf. Ps $102^{\mathrm{MT}}$ ), but in Hebrews 1:10-12 the Kyrios is used as a reference to the Son; the same applies to Acts 2 where Kyrios, as in $\mathrm{YHWH}$, is interpreted as reference to Jesus. No one in his compos Judean mentis would argue against the fact that no enemy in heaven or on earth stands a 'fighting' chance against YHWH as ruler (Heb 1:11-12). But when this idea is expressed by Theos in relation to his Son, it cannot be deemed anything other than beyond reproach. In Hebrews 1:13a, the author introduces yet another rhetorical question, ${ }^{45}$ whether Theos has ever said anything like this about the angels (Heb 1:13a), followed by a quote resembling Psalms 109:1b-c (Heb 1:13b). In Acts 2:34b, the author also relies on Psalms 109:1a to make the point that David did not ascend into heaven, but that Kyrios, as in Jesus, did. The author of Hebrews has no interest in highlighting the Davidic kingship, but remains true to his premise and allows Theos to interpret the Psalm as to contrast the angels with the Son. The content reflecting Psalms 109:1b-c is again used to reaffirm the authoritative position and status of the Son in comparison to the angels and not to give authority to the subject matter by evoking a Davidic memory. The author allows Theos to draft the cosmological-authoritarian theology by way of strategically deploying citation after citation, innovative yet traditional.

\section{Conclusion}

The theologies produced by the authors of Acts 2 and Hebrews 1 is a conflation of apostolic speech, prophecy, divine speech, the Spirit and the authoritative Son - all appropriate ingredients to construct theologies. There is, however, one 'secret' ingredient that will not only predict the theological 'flavour', but also determine the very structure of that which is being produced, and this secret ingredient is Old Testament citations. It makes the act of remembering, reimaging and reinterpreting possible. It is to keep to promises and to fulfil prophecies (predominant in Ac 2); it offers a vocabulary, a voice to Theos. It confirms the authoritative positionality and identity of the Son, making him the prophet, prophecy and fulfilment (predominant in Hebrews 1). In the broadest possible terms, the study set out to show and determine how the Hebrew Scriptures (Old Testament citations) shape the theologies produced in Acts 2 and Hebrews 1. It wanted to accentuate the discrepancies, peculiarities and inconsistencies of how they define, interpret and apply Old Testament content. To this end, the study made the reader aware of its hypothesis, that Acts 2 produces a memory-induced theology, classified as traditional universalism, whereas Hebrews 1 produces a cosmological-authoritarian theology, defined as creative 45.Cf. Hebrews 1:5a. traditionalism and that it postulates that the respective propositions on offer in Acts 2 and Hebrews 1 are key to the theologies produced. The study remained true to the hypothesis set forth and the postulation, which formed the basis of the text analysis. It is therefore plausible to assert that for the author of Luke-Acts, Jesus becomes a 'passive' heavenly figure when he is taken up into heaven (cf. Ac 1:11). $\mathrm{He}$ has neither any interest to nurture or develop a cosmological theology of abstraction nor to theorise about the cosmological identity and positionality of Jesus. The reason is that it does not serve the purpose of establishing and expanding the kingdom of Theos. What he is interested in is how Jesus' ideas of the kingdom of Theos are rooted in the prophetic past and that it is taken forward and further. To this end, he introduces and develops the $\pi v \varepsilon \tilde{v} \mu \alpha$ concept as the necessary divine subject matter that gives one the mandate, authority and ability to establish and expand the kingdom of Theos. It is a memory infused, prophetically fulfilled and pneumatologically expanding theology. The citations provide the framework for remembering, affirming and establishing the history of tradition, whereas the $\pi v \varepsilon \tilde{v} \mu \alpha$ concept allows for reimagining. The key is for the human agents to be equipped with the $\pi v \varepsilon \tilde{v} \mu \alpha$ for the traditional theology to become accessible, attainable and re-imaginable for all. Therefore, Acts 2 ultimately offers a traditionaluniversal, decentralised theology; it is a theology that is horizontally orientated with the aim to multiply.

In addition, Hebrews 1 represents a position that is on the opposing end of the theological spectrum. The theology in Hebrews 1 can be characterised as cosmological in character, a vertical orientated theology; it is a theology from above. It introduces a theology of singularity, a centralisation theology. The Son is promoted to the highest transcendental office, the heir of everything and the maker of all ages. The Son is even promoted to a position far more superior than that of the angels. The citations become the voice of Theos. It is the direct access to the will and expression of Theos with the aim to substantiate and affirm the position, role and authority of the Son. Broadly defined, the theology of Acts 2 is a continuation of the theology rooted in Judaism, it is fluid as it moves from the old to the new. The theology found in Hebrews 1 is a redefining, realigning and reassessment of Judaism; hence, it offers a position of discontinuation. ${ }^{46}$ The theology of Acts does not look up to the clouds, but turns around to acknowledge the past to affect the present and build the future. As for the theology of Hebrews, it journeyed with the Son into heaven and develops its theology from there.

Our theologies often play a significant role in how we use our respective authoritative religious texts when responding to our respective circumstances. There is no single, appropriate and 'authoritative' theological response. The value rather is to celebrate theological varieties, possibilities and variations. This study argues for the acknowledgement and affirmation of a spectrum of theological possibilities in dialogue, which is open for reflection and criticism.

46.Wilckens (2011:307), who asserted that the divine speech is the aspect that ensures continuity. 


\section{Acknowledgements Competing interests}

The author declares that he has no financial or personal relationships that may have inappropriately influenced him in writing this article.

\section{Author's contributions}

P.N. is the sole author of this article.

\section{Ethical considerations}

This article followed all ethical standards for research without direct contact with human or animal subjects.

\section{Funding information}

This research received no specific grant from any funding agency in the public, commercial or not-for-profit sectors.

\section{Data availability}

Data sharing is not applicable to this article as no new data were created or analysed in this study.

\section{Disclaimer}

The views and opinions expressed in this article are those of the author and do not necessarily reflect the official policy or position of any affiliated agency of the author.

\section{References}

Black, D.A., 1987, 'Hebrews 1:1-4: A study in discourse analysis', The Westminster Theological Journal 49(1), 175-194.

Bormann, L., 2017, Theologie des Neuen Testaments, Vandenhoeck \& Ruprecht, Göttingen.

Cockerill, G.L., 2012, The Epistle to the Hebrews, The New International Commentary on the New Testament, Eerdmans, Grand Rapids, MI.
Docherty, S., 2009, 'The text form of the OT citations in Hebrews Chapter 1 and the implications for the study of the Septuagint', New Testament Studies 55(3), 355-365. https://doi.org/10.1017/S0028688509000253

Galinsky, K., 2016, 'Introduction', in K. Galinsky (ed.), Memory in ancient Rome and early Christianity, pp. 1-39, Oxford University Press, Oxford.

Goodman, M., 1997, The Roman World: $44 B C-A D$ 180, Routledge, London.

Guthrie, G.H., 2007, 'Hebrews', in G.K. Beale \& D.A. Carson (eds.), Commentary on the New Testament use of the Old Testament, pp. 1653-1784, Baker Academic, Grand Rapids, MI.

Hahn, F., 2011a, Theologie des Neuen Testaments, Bd. I: Die Vielfalt des Neuen Testaments, Mohr Siebeck, Tübingen.

Hahn, F., 2011b, Theologie des Neuen Testaments, Bd. II: Die Einheit des Neuen Testaments, Mohr Siebeck, Tübingen.

Hutton, R.R., 1992, 'Korah (Person)', in D.N. Freedman (ed.), The Anchor Yale Bible Dictionary, pp. 100-101, Doubleday, New York, NY.

Jervell, J., 1998, Die Apostelgeschichte. KEK, III, Vandenhoeck \& Ruprecht, Göttingen.

Kilgallen, J.J., 2002, “"With many other words" (Acts 2,40): Theological assumptions in Peter's Pentecost speech', Biblica 83(1), 71-87.

Kuiper, K. (ed.), 2011, The Britannica guide to ancient civilisations - Ancient Rome from Romulus and Remus to the Visigoth invasion, Britannica Educational Publishing, New York, NY.

Longenecker, R., 1975, Biblical exegesis in the Apostolic period, Eerdmans, Grand Rapids, MI.

Meier, J.P., 1985, 'Structure and theology in Heb 1:1-14', Biblica 66(2), 168-189.

Moreland, M., 2016, 'Moving Peter to Rome - Social memory and ritualized space after 70 CE', in K. Galinsky (ed.), Memory in ancient Rome and early Christianity, pp. 344-366, Oxford University Press, Oxford.

Nagel, P., 2018, 'The Schechina concept(s) in Acts: The formation potential of Old Testament citations', Neotestamentica 51(1), 113-127. https://doi.org/10.1353/ neo.2017.0006

Potter, D., 2013, The Emperors of Rome: The story of imperial Rome from Julius Caesar to the last emperor, Quercus Editions Ltd, London.

Schnelle, U., 2007, Theologie des Neuen Testaments, Vandenhoeck \& Ruprecht, Göttingen.

Schröter, J., 2013, From Jesus to the New Testament - early Christian theology and the origin of the New Testament canon, transl. W. Coppins, Baylor University Press, Waco, TX

Steel, C., 2010, 'Hebrews 1:1-4', Interpretation 64(3), 290-292. https://doi. org/10.1177/002096431006400307

Steyn, G.J., 2011, A quest for the assumed LXX Vorlage of the explicit quotations in Hebrews, Vandenhoeck \& Ruprecht, Gottingen.

Stock, A-K., Gasar, H. \& Güntürkün, O., 2016, 'The neuroscience of memory', in K. Galinsky (ed.), Memory in ancient Rome and early Christianity, pp. 369-392, Oxford University Press, Oxford.

Talbert, C.H., 2005, Reading Acts - A literary and theological commentary on the Acts of apostles, Smyth \& Helwys Publishing, Macon, GA.

Wedderburn, A.J.M., 1995, 'Traditions and redaction in Acts 2:1-13', Journal for the Study of the New Testament 17(55), 27-54. https://doi.org/10.1177/0142064X 9501705502

Wilckens, U., 2011, Theologie des Neuen Testaments. Band I: Geschichte der urchristichen Theologie, Neukirchener, Vluyn. 